\title{
MI DEUDA FILOSÓFICA CON VICO
}

\section{Moisés González García (U.N.E.D.)}

\begin{abstract}
RESUMEN: El Autor realiza una mirada retrospectiva sobre su vinculación con el estudio de Vico, para llegar a afirmar que hoy día sigue creyendo que el pensamiento de Vico encierra un enorme potencial y tiene mucho que decir a una época como la nuestra que vive en un desconcierto semejante al de tantas otras épocas que ya fueron, y al de otras que todavía están por venir.

Palabras ClaVE: Vico, $350^{\circ}$ Aniversario, historia, comprensión, Ciencia nueva, naciones, humanidad, M. González García.
\end{abstract}

\section{My philosophical debt with Vico}

ABSTRACT: The Author takes a retrospective look at his relationship with Vico's study in order to say that he still believes that Vico's thought contains an enormous potential, and still has much to say in an era like ours, which lives in a similar confusion to the one that characterized many other times of the past, and more that will arrive in the future.

KEYwords: Vico, $350^{\text {th }}$ Anniversary, history, understanding, New science, nations, humanity, M. González García.

\section{Il mio debito filosofico con Vico}

RIASSUNTO: L'Autore offre uno sguardo retrospettivo sul proprio legame con lo studio di Vico, per arrivare ad affermare che, ancora oggi, crede nell'enorme potenziale del pensiero del pensiero vichiano e che esso abbia ancora molto da dire a un'epoca come la nostra la quale, in fondo, vive una confusione simile a quella di tante epoche passate e di altre ancora da venire.

PAROLE ChIAVE: Vico, $350^{\circ}$ Anniversario, storia, comprensione, Sciencia nuova, nazioni, umanità, M. González García.

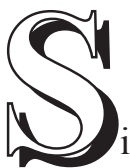

i en este momento de mi vida hiciese un recorrido por la historia de la filosofía para ver qué filósofos han influido más en mi pensamiento, no tengo la menor duda de que Vico ocuparía un lugar destacado. Sobre él hice mi tesis doctoral en 1975: Hombre e Historia en J.B. Vico, en la Universidad Complutense de Madrid. A partir de entonces su pensamiento me ha acompañado a lo largo de mi vida intelectual y a él he dedicado algunos de mis trabajos. Me referiré brevemente ahora a enunciar algunas de las principales aportaciones que, desde mi punto de 
vista, hizo Vico al pensamiento filosófico y que, en todo caso, más han influido en mis reflexiones filosóficas.

Ante todo, haber puesto de manifiesto que el pensamiento filosófico tiene necesariamente que dirigir su mirada al problema del hombre. Y es que, en último término, en filosofía se trata siempre de nosotros mismos, esto es, del hombre. En este sentido, Vico se preocupó de una forma constante a lo largo de toda su vida y de su obra en reivindicar que el pensamiento por antonomasia debía convertirse en ciencia del hombre. El pensador napolitano pretende encontrar un nuevo curso al filosofar que nos proporcione una nueva filosofía del hombre que él creía que había faltado hasta entonces. En su opinión el mundo de la historia, puesto que ha sido hecho por los hombres, se convierte en el único camino metodológico que nos puede proporcionar un verdadero conocimiento del ser humano. La "verdad del hombre" habrá que buscarla en las obras que el hombre ha hecho a través de su obrar histórico. La "Ciencia nueva" viene a ser para Vico la ciencia del hombre en la historia. Si queremos conocer al hombre tenemos que conocer la historia en la que expresa todas sus posibilidades y, en definitiva, lo que es. La historia deja de ser un caos de acontecimientos para convertirse en un método indispensable para el conocimiento del ser humano.

Para Vico lo que determina y define el ser del hombre, su naturaleza, es su acción. La naturaleza del hombre, nos dice, es «esa divina facultad de hacer». Habrá, pues, que construir la filosofía del hombre a partir de las grandes obras humanas: la religión, el lenguaje, el mito, el derecho, las instituciones... En ellas hemos de buscar no tanto sus innumerables formas y manifestaciones, sino su sentido o, como dice Vico, «su significado y verdad».

Otro de los aspectos más destacables del pensamiento viquiano es el valor metodológico de los orígenes para el conocimiento del hombre. Para Vico no puede haber ciencia alguna, ni del hombre ni de la historia humana, sin la certeza de sus principios. Así nos lo expresa con toda claridad cuando en el párrafo 147 de la Ciencia nueva de 1744 nos dice que: «la naturaleza de las cosas no es sino el nacimiento de ellas en determinados tiempos y en determinadas circunstancias». La insistencia de Vico en buscar en los tiempos primitivos el origen de la civilización humana lo condujo al descubrimiento del momento fantástico-poético del espíritu humano, que es uno de los logros más importantes de su pensamiento. Los pueblos primitivos, nos dirá, fueron por naturaleza sublimes poetas. Lo poético es, para él, en primer lugar y fundamentalmente, creación. En consecuencia la época primitiva, que fue poética, creó la civilización humana.

Frente a aquellos que ven las antiguas fábulas simplemente como fruto de la ignorancia de los pueblos primitivos, debiendo procederse a liberar la mente de la influencia de la fantasía y de los sentidos en cuanto fuentes de ilusiones y engaños, Vico pretende con su Ciencia nueva sumergirse de lleno en ese instante originario 
con el que da comienzo el proceso de humanización. Son tiempos remotísimos y oscuros, pero es allí donde podemos descubrir cómo los «bestioni» comenzaron humanamente a pensar, allí es donde se esconde el misterio del ser humano. Nosotros tenemos una historia a nuestras espaldas, y para desenredar la trama humana necesitamos traer a la luz esa naturaleza originaria del hombre y todas aquellas manifestaciones que a lo largo del tiempo nos han dejado nuestros antepasados.

Finalmente, me gustaría destacar la importancia que Vico asigna, además de a la construcción de lo humano, a lo que podríamos denominar el porvenir del género humano. Vico nos presenta la historia de las naciones como un proceso de humanización creciente que, partiendo de la barbarie propia de los pueblos primitivos o «barbarie del senso», terminará por desembocar en la edad de los hombres, que corresponde a un desarrollo pleno de la racionalidad, de una «ragione tutta spiegata» que reconozca la igualdad natural de todos los hombres y establezca «repúblicas populares» $\mathrm{y}$ «gobiernos humanos»: «El orden de las cosas humanas es el siguiente: primero existieron las selvas, después las chozas, después los poblados, luego las ciudades, y finalmente las academias». ${ }^{1}$ Vico manifiesta una gran confianza en la razón y en el porvenir del género humano. «El mundo es todavía joven», dice en su De mente heroica (1732) a los jóvenes estudiantes para que no se dejen vencer por el desánimo y busquen avanzar en nuevos descubrimientos y nuevas mejoras para la humanidad. Pero este evidente optimismo no puede llevarnos a creer que Vico crea que el proceso histórico pueda conducir a los hombres a convertirse en una especie de dioses en medio de una sociedad paradisíaca, pues la barbarie está siempre presente y puede retornar a sus formas más salvajes. Efectivamente el pensador napolitano considera que el progreso ni es una necesidad que se tenga que producir inevitablemente, ni mucho menos es irreversible, pues los conflictos, las luchas, las miserias humanas, la decadencia y la degeneración están siempre presentes y son siempre posibles. La época propiamente humana debe ser vista como tiempo de la frágil perfección. En la "Conclusión de la obra" de la Ciencia nueva de 1744 Vico introduce el concepto de la «barbarie de la reflexión» para referirse a una barbarie terminal, que es la de la decadencia y de la disolución, de la desintegración social que genera condiciones bárbaras, de violencia, de fuerza, de desigualdad, de tiranía, de anarquía, previas al colapso final. Se ha discutido mucho sobre lo que Vico entiende por tal concepto y si su aparición es una simple posibilidad o una necesidad irremediable. ${ }^{2}$ En todo caso, Vico atribuye a la filosofía, una vez surgida, la responsabilidad fundamental de humanizar las costumbres y las instituciones, debiendo convertirse en punto de referencia y centro de toda la

1. SN44, en Opere, ed. de A. BatTistini, Mondadori, Milán, 1990, p. 519.

2. Véase a este respecto mi artículo: "De la racionalidad a la barbarie de la reflexión en Giambattista Vico", en Pensar para el nuevo siglo. Giambattista Vico y la cultura europea, E. Hidalgo-Serna, M. Marassi, J.M Sevilla, J. VilLalobos (editores), Ed. La cittá del sole, Nápoles, 2001, vol. III, pp. 1.041-1.061. 
vida civil, actuando, en consecuencia, como guía moral y política. Pero eso ocurrirá siempre y cuando no se aleje del camino de la verdad y no se convierta en «madre de la mentira», pues entonces no hará otra cosa que encaminar a la humanidad hacia la barbarie.

Quisiera concluir esta breve disertación señalando que hoy sigo creyendo que el pensamiento de Vico encierra un enorme potencial y tiene mucho que decir a los hombres de una época como la nuestra que vive en un desconcierto semejante al de tantas otras épocas que ya fueron, y al de otras que todavía están por venir. Creo que Vico abrió un nuevo camino en lo que se refiere a la comprensión del hombre y de su historia, poniendo de manifiesto todo lo que la filosofía puede hacer por el hombre. Con razón reivindica en su Autobiografía el derecho a ser recordado como autor de la Ciencia nueva. ${ }^{3}$ En ella nos muestra que su filosofía fue fruto de una pasión, de una gran pasión que busca abrir los claustros de la verdad para comprender la realidad en la que nosotros mismos nos encontramos. Establecer un diálogo con sus escritos resultará de gran utilidad para que la filosofía actual recupere su voz y sea capaz de pensar el hoy y el ahora.

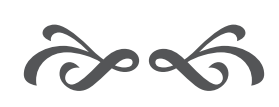

3. Autobiografía de Giambattista Vico, edición de J. Martínez Bisbal y M. González García, Siglo XXI Ed., 1998, Madrid, p. 189. 